\title{
Methods and Devices Used in Determining the Quality of Electric Wires Terminal Crimping
}

\author{
Umut Emre Uzun ${ }^{1}$, Turgut Karademir ${ }^{2}$, Nihat Pamuk ${ }^{3 *}$, Nevzat Onat ${ }^{4}$ \\ ${ }^{1}$ Zonguldak Bulent Ecevit University, Faculty of Engineering, Departmant of Electrical and Electronics Engineering, Zonguldak, Turkey, \\ (ORCID: 0000-0002-6209-2962), umut.uzun@beun.edu.tr \\ 2 Manisa Celal Bayar University, Faculty of Engineering, Departmant of Electrical and Electronics Engineering, Manisa, Turkey, \\ (ORCID: 0000-0001-9044-1552), karademir.turgut.elk@yandex.com \\ $3^{*}$ Zonguldak Bulent Ecevit University, Faculty of Engineering, Departmant of Electrical and Electronics Engineering, Zonguldak, Turkey, \\ (ORCID: 0000-0001-8980-6913), nihatpamuk@gmail.com \\ ${ }^{4}$ Manisa Celal Bayar University, Faculty of Engineering, Departmant of Electrical and Electronics Engineering, Manisa, Turkey, \\ (ORCID: 0000-0002-2244-4441), nevzat.onat@.cbu.edu.tr
}

(First received 24 June 2021 and in final form 22 August 2021)

(DOI: $10.31590 /$ ejosat.957230)

ATIF/REFERENCE: Uzun, U. E., Karademir, T., Pamuk, N. \& Onat, N. (2021). Methods and Devices Used in Determining the Quality of Electric Wires Terminal Crimping. European Journal of Science and Technology, (27), 221-227.

\begin{abstract}
In this study, it is planned to investigate the analysis methods and devices used for analysis in the quality determination of terminal crimping in the rapidly developing and growing ready-made electrical cable manufacturing sector. Electric cables are used both in data exchange and transmission of electric current. For this reason, it is always desired that its assembly be done easily and reliably. For this, a connection element called terminal is placed at the end of the cable. This process is called terminal crimping. Terminal crimping can be performed manually with the help of crimping pliers or with semi-automatic or fully automatic machines. However, the process may not always be performed in the desired quality. Losses in data transmission may occur as a result of poor quality crimping. In the transmission of electrical current, undesirable events such as cable heating, explosion, fire may occur as a result of bad contact. For this reason, some quality control devices or test platforms to be designed are needed to determine the quality of the terminal crimping operations. Determination of the crimp quality in existing quality control devices is mainly made by electrical testing, cross-sectional imaging and force analysis methods. In this study, comparative analysis of methods and tools for determining the crimp quality in cable manufacturing industry has been made. Defects that may be encountered in crimp processes and their characteristics are revealed, and the reasons for preference, advantages and disadvantages of destructive/non-destructive quality control techniques are summarized.
\end{abstract}

Keywords: Cable manufacturing, Terminal crimping, Crimping quality, Quality control methods.

\section{Elektrik Kabloları Terminal Çakım Kalitesini Belirlemede Kullanılan Yöntem ve Cihazlar}

$\ddot{O} z$

Bu çalışmada, günümüzde hızla gelişen ve büyüyen hazır elektrik kablosu imalat sektöründe terminal çakım (krimpleme) işleminin kalite tespitinde kullanılan analiz yöntemlerinin ve analiz için kullanılan cihazların araştırılması planlanmıştır. Elektrik kabloları hem veri alışverişinde hem de elektrik akımının iletiminde kullanılmaktadır. Bu nedenle montajının her zaman kolay ve güvenilir bir şekilde yapılması istenir. Bunun için kablonun ucuna terminal adı verilen bağlantı elemanı yerleştirilir. Bu işleme terminal çakımı (krimpleme) adı verilir. Terminal çakım işlemi sıkma pensesi yardımı ile manuel olarak ya da yarı otomatik veya tam otomatik makineler ile gerçekleştirilebilir. Ancak yapılan işlem her zaman istenilen kalitede gerçekleştirilemeyebilir. Kalitesiz çakım işlemi sonucunda veri iletiminde kayıplar yaşanabilir. Elektrik akımının iletiminde ise kötü temas sonucu kablo ısınmaları, patlama, yangın gibi istenmeyen olaylar olabilir. Bu nedenle yapılan terminal çakım işlemlerinin kalitesinin belirlenmesi için bazı kalite kontrol cihazlarına veya tasarlanacak test platformlarına ihtiyaç duyulmaktadır. Mevcut kalite kontrol cihazlarında çakım kalitesinin belirlenmesi temel olarak elektriksel test, kesit görüntüleme ve kuvvet analizi yöntemleri ile yapılmaktadır. Bu çalışmada kablo işleme endüstrisinde çakım kalitesini belirleme yöntemleri ve araçlarının karşılaştırmalı analizi yapılmıştır. Çakım işlemlerinde karşılaşılabilecek hatalar ve özellikleri ortaya konularak, tahribatlı/tahribatsız kalite kontrol tekniklerinin tercih nedenleri, avantaj ve dezavantajları özetlenmiştir.

Anahtar Kelimeler: Kablo imalatı, Terminal çakımı, Çakım kalitesi, Kalite kontrol yöntemleri.

* Corresponding Author: nihatpamuk@gmail.com 


\section{Introduction}

Today, electrical cables are used for electrical power and signal transmission in the white goods, automotive and defense industry, biomedical devices and many other areas. After the manufacturing phase, electrical cables are subjected to a process called cable grouping. Cable grouping is the process of determining the properties of electrical cables and classifying them according to certain standard. After this process, the cable end is stripped and the terminal crimping process is performed.

Crimping is the most preferred method used to connect the an electrical cable with a the terminal (Ogihara, Takata, Hattori, \& Yoshida, 2006). Terminal crimping is the process of placing the connection element called "terminal" or "connector" at the end of the cable in order to provide permanent electrical contact, to realize electrical power and signal transmission without noise and to increase safety (Ocoleanu, Cividjian, \& Manolea, 2014). This process is performed by deforming the open or closed terminal leg on the cable by mechanical pressure, which is called cold welding (Elliott, 2007). Figure 1 shows samples of the most used classical and insulation displacement terminals (IDC) in this sector.

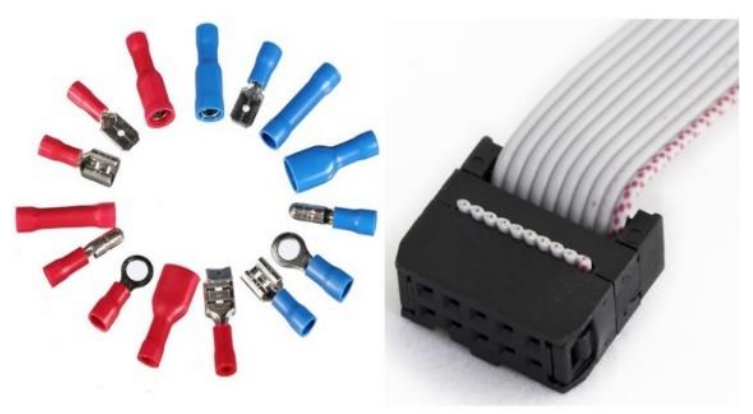

Figure 1. Classic and IDC terminal samples

Terminal crimping can be done manually by a person with a tool called crimping pliers. At the same time, crimping can be performed with semi-automatic or fully automatic machines that is available in the industry. Figure 2 shows the crimping pliers and the terminal crimping machine.
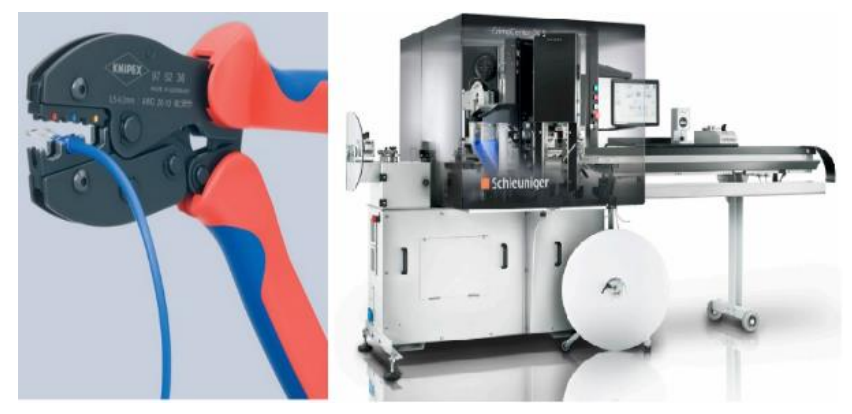

Figure 2. Terminal crimping pliers and terminal crimping machine (Knipex, 2019; Schleuniger1, 2019)

In terminal crimping operations, there should always be the highest level of mechanical and electrical connection between cable and terminal (Ocoleanu \& Dolan, 2018). Since the terminal crimping process is a very complicated process, it is influenced by many factors (Fan, Gao, $\mathrm{Li}, \& \mathrm{Xu}, 2012$ ). So the summarized errors in Table 1 may occur in terminal crimping.
Table 1. Analysis of error types that will may occur in terminal crimping process (Deveci, 2013)

\begin{tabular}{|c|c|c|}
\hline Error Type & Error Description & Error Result \\
\hline $\begin{array}{l}\text { Low cable cross- } \\
\text { section }\end{array}$ & $\begin{array}{l}\text { It is the case of } \\
\text { using a cable with a } \\
\text { cross section other } \\
\text { than the specified } \\
\text { cable section. }\end{array}$ & $\begin{array}{l}\text { The cable may } \\
\text { cause overheating } \\
\text { and fire. } \\
\text { Transmission errors } \\
\text { may occur as a } \\
\text { result of loose } \\
\text { contact between the } \\
\text { cable and terminal } \\
\text { connection. }\end{array}$ \\
\hline $\begin{array}{l}\text { Damaging to copper } \\
\text { wires during cable } \\
\text { cutting }\end{array}$ & $\begin{array}{l}\text { It is the case of } \\
\text { breaking or thinning } \\
\text { of copper wires } \\
\text { during cutting. It is } \\
\text { dangerous. Terminal } \\
\text { heating may occur } \\
\text { in the final product. }\end{array}$ & $\begin{array}{l}\text { When in the copper } \\
\text { wire occur breaking, } \\
\text { the product becomes } \\
\text { junk. }\end{array}$ \\
\hline $\begin{array}{l}\text { Cutting copper wires } \\
\text { during cable } \\
\text { stripping (stripping } \\
\text { knife error) }\end{array}$ & $\begin{array}{l}\text { While stripping } \\
\text { knife is stripping the } \\
\text { insulation part, it is } \\
\text { the case of cutting } \\
\text { or damaging the } \\
\text { copper wire. }\end{array}$ & $\begin{array}{l}\text { It causes to become } \\
\text { hot in the terminal } \\
\text { and lose its } \\
\text { function. }\end{array}$ \\
\hline $\begin{array}{l}\text { Not being at the } \\
\text { desired value of } \\
\text { crimp height }\end{array}$ & $\begin{array}{l}\text { If the crimp height } \\
\text { is not at the desired } \\
\text { value, it means that } \\
\text { the terminal is close } \\
\text { or far from the cable } \\
\text { end. }\end{array}$ & $\begin{array}{l}\text { It causes to become } \\
\text { hot in the terminal } \\
\text { and lose its } \\
\text { function. }\end{array}$ \\
\hline $\begin{array}{l}\text { Not being at the } \\
\text { suitable features of } \\
\text { crimping }\end{array}$ & $\begin{array}{l}\text { If the crimping on } \\
\text { the cable ends is } \\
\text { wrong, there may be } \\
\text { problem in the } \\
\text { connection of the } \\
\text { cable with the } \\
\text { terminal or there } \\
\text { may be visual } \\
\text { disturbance. }\end{array}$ & $\begin{array}{l}\text { It causes assembly } \\
\text { difficulties or visual } \\
\text { disturbances. }\end{array}$ \\
\hline
\end{tabular}

Crimping operations that have one or more of these errors are called poor quality crimping. Cables that are used in many places and purposes are exposed to vibration, temperature change and electrical environment (Rajak \& Kore, 2017; Rajak \& Kore, 2018).

For this reason, in data transmission cables, data loss problem can be experienced as a result of poor quality crimping. On the other hands, in electrical transmission cables, problems such as separation of the terminal from the cable can be experienced as a result of electrical heating and vibration. As a result of such possible problems, fire, device failure, loss of life and property may occur.

While some of the errors in Table 1 can be detected visually, some of them are almost impossible to detect visually. For this reason, different methods and analyzes have been carried out in order to detect the errors that occur in the crimping process. 


\section{Material and Method}

\subsection{Crimp Quality Measurement Methods}

Depending on the application method, three methods come to the fore for the determination of the crimp quality. These; electrical test, cross-sectional imaging and force analysis. In addition, quality control methods can be classified into two main groups as destructive and non-destructive. In destructive methods, quality analysis is performed by samples taken from a certain number of products. Therefore, in result of the process, the cable is destroyed and scrapped. Although these methods are widely used, the reliability is low since the control of every manufactured product is not realized. The first two of the three methods mentioned above (electrical test and cross-section imaging) are sample-based methods. The more innovative method is the force analysis method, and this method has two different approaches. In this study, briefly the first two methods will be examined. Mainly force analysis methods will be examined.

\subsubsection{Electrical Test}

In the electrical test, resistance profiles are created by taking samples from the cables made of a certain number of crimping. To measure the resistance, a test current is applied to the cable and the voltage drop on the cable is detected. The resistance value is calculated with "Ohm's Law" and the resistance profile of the sample is created (Camiresearch1, 2015). It is possible to perform electrical tests of both low voltage and high voltage cables with the devices that is available in the industry. In general, the measured resistance value varies according to the cable crosssection, length and the voltage and current range of the cable. In addition, this test only provides information about electrical performance, not mechanical performance. Therefore, serious difficulties arise regarding the stability of test results. An electrical test device can be seen in Figure 3.

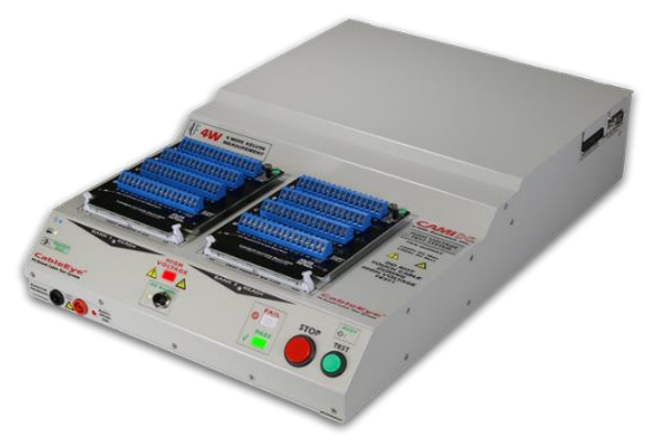

Figure 3. Electrical test device (Camiresearch2, 2021)

\subsubsection{Cross- Section Imaging}

In the cross-section imaging process, samples are taken from the cables made of a certain number of crimping. For this process, the crimp micrograph analyzer (crimp cross-section analyzer) is used. The samples are cut, polished, cleaned and made ready for examination under the microscope (Schleuniger2, 2018). The examination process is done under laboratory conditions with digital microscopes. This process takes about 5 minutes. This process, which requires laboratories and expensive equipment, also requires qualified workforce. Figure 4 shows the crimp micrograph analyzer. Samples are examined under a digital microscope and transferred to a computer environment.

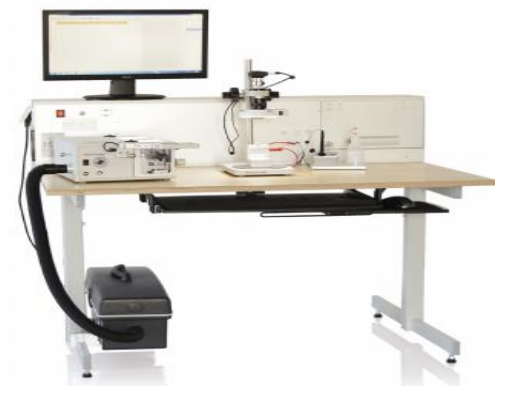

Figure 4. Crimp micrograph analyzer (Schleuniger2, 2018)

Figures 5(a)-(b) are the cross-sectional views of the right crimping process. In quality crimping, the terminal legs should hold the conductive wires in a honeycomb structure. There should be no gap between the conductive wires and the terminal leg should not over tighten the conductors.

Figure 5(c)-(d)-(e)-(f) are cross-sectional views of the faulty crimping samples. In Figure 5(c), the terminal legs did not tighten the conductor wires sufficiently and some of the conductor wires were out. In Figure 5(d) and (e), there are gaps between conductive wires. In Figure 5(f), the terminal legs touched the terminal base by excessively tightening.
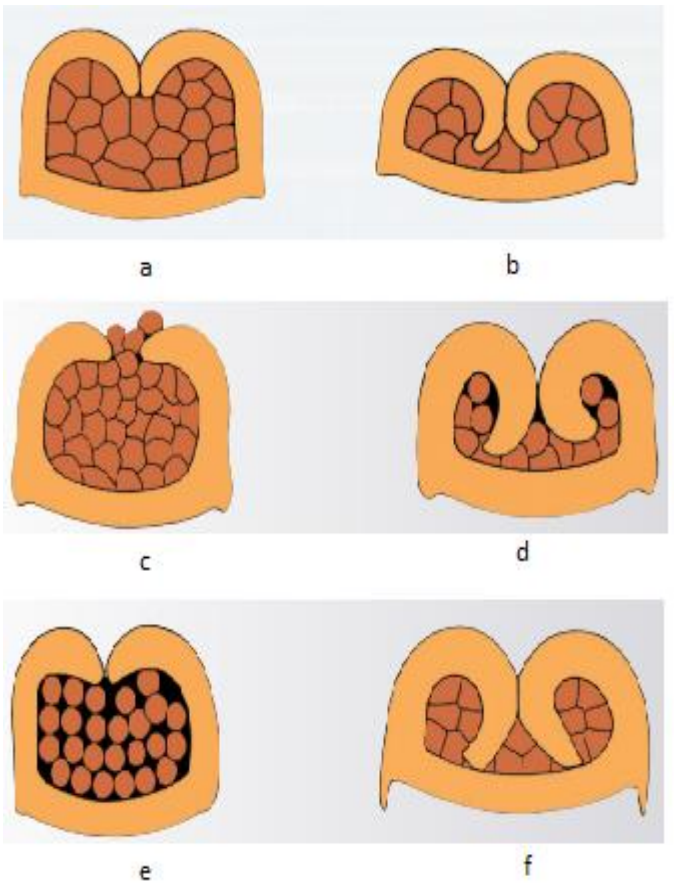

Figure 5. Correct and incorrect crimp section images (TEConnectivity, 2019)

\subsubsection{Force Analysis}

Strength test of the terminal crimped cable is performed with the force analysis method. The strength test is a test that allow to be interpreted both electrically and mechanically of the terminal crimping process. Applying the correct force in the crimping process prevents the occurrence of erroneous crimping, shown in Figure 5, and ensures a correct crimping. As a result of correct crimping, both mechanical and electrical performance will be high. Two types devices used in the industry stand out for force analysis. 


\subsubsection{Pull Tester}

There is a terminal head and a vice on pull tester. In the terminal head, each groove is designed according to standard cable cross sections. The motor located under the vice pulls the cable in a single axis at a constant speed. This speed should be in the range of 50-250 $\mathrm{mm}$ per minute according to USCAR (Standard1, 2018). The pull test can be performed in 3 different ways. These:

- Pull and Release: It is a non-destructive method in which the terminal is pulled up to a certain force and then the pulling force is removed.

- Pull and Hold: It is a non-destructive method in which the terminal is pulled up to a certain force and held at this force for a certain period of time. The pulling force is reduced to zero after the process.

- Pull, Hold and Break: It is a destructive method in which the terminal is pulled up to a certain force, held at this force for a certain time, and more pulling force is applied until the terminal is finally seperated from the cable.

Pull tester generally work with the Pull, Hold and Break method. Table 2 shows the minimum breaking values of the IEC 60352-2 standard used in solderless connections (Standard2, 2013). The cable placed in the device is pulled until terminal seperates from the cable. As a result of the pulling process, the breaking value and the minimum breaking value are compared by the operator or device. If the breaking value is lower than the minimum breaking value, it is determined that the crimping is poor quality. If the breaking value is higher than the minimum breaking value, it is determined that the crimping is good quality.

Table 2.Minimum breaking values for solderless connections according to IEC 60352-2 standard

\begin{tabular}{|c|c|c|}
\hline \multicolumn{2}{|c|}{ Conductor Cross Section } & \multirow{2}{*}{$\begin{array}{c}\text { Minimum Breaking } \\
\text { Force } \\
\mathbf{N} \\
\end{array}$} \\
\hline $\mathbf{m m}^{2}$ & AVG* & \\
\hline 0.05 & 30 & 6 \\
\hline 0.08 & 28 & 11 \\
\hline 0.12 & 26 & 15 \\
\hline 0.14 & & 18 \\
\hline 0.22 & 24 & 28 \\
\hline 0.25 & & 32 \\
\hline 0.32 & 22 & 40 \\
\hline 0.5 & 20 & 60 \\
\hline 0.75 & & 85 \\
\hline 0.82 & 18 & 90 \\
\hline 1 & & 108 \\
\hline 1.3 & 16 & 135 \\
\hline 1.5 & & 150 \\
\hline 2.1 & 14 & 200 \\
\hline 2.5 & & 230 \\
\hline 3.3 & 12 & 275 \\
\hline 4 & & 310 \\
\hline 5.3 & 10 & 355 \\
\hline 6 & & 360 \\
\hline 8.4 & 8 & 370 \\
\hline 10 & & 380 \\
\hline & ional $\mathrm{p}$ & \\
\hline
\end{tabular}

The pull tester is a device that is made by taking random samples from the cables that are terminal crimped and generally performed destructively. Figure 6 shows the pull tester. The device reads the force values when the operator pulls the vise. The read force values are printed on the screen and the breaking value is recorded.

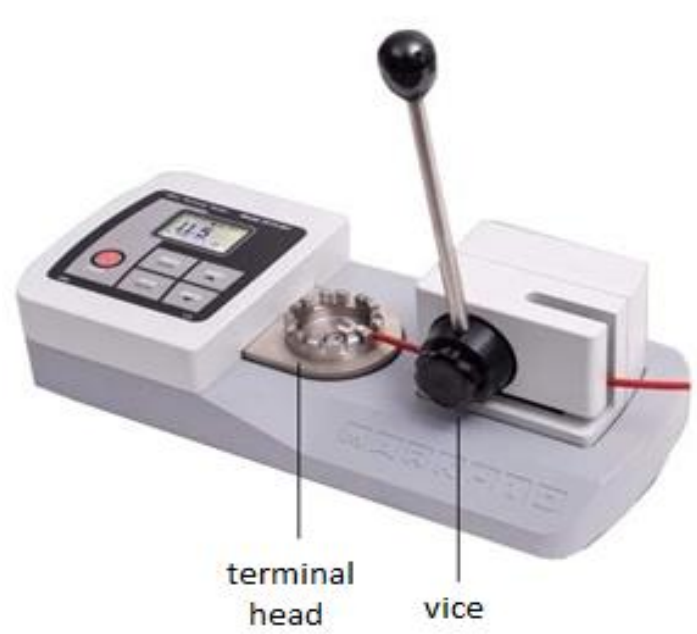

Figure 6. Pull tester (Mark-10, 2020)

\subsubsection{Crimp Force Analyzer or Monitoring}

There is a press system in terminal crimping machines to perform the crimping process. There is generally a piezoelectric force sensor under the area where the crimping process is performed. The sensor uses the piezoelectric effect to show the change in force. Piezo prefix is used in Greek in the meaning of press. Monitoring the force-time graph of the press system in the crimp force analyzer is provided by a piezoelectric force sensor. Figure 7 shows the combined use of the press and the crimp force analyzer.

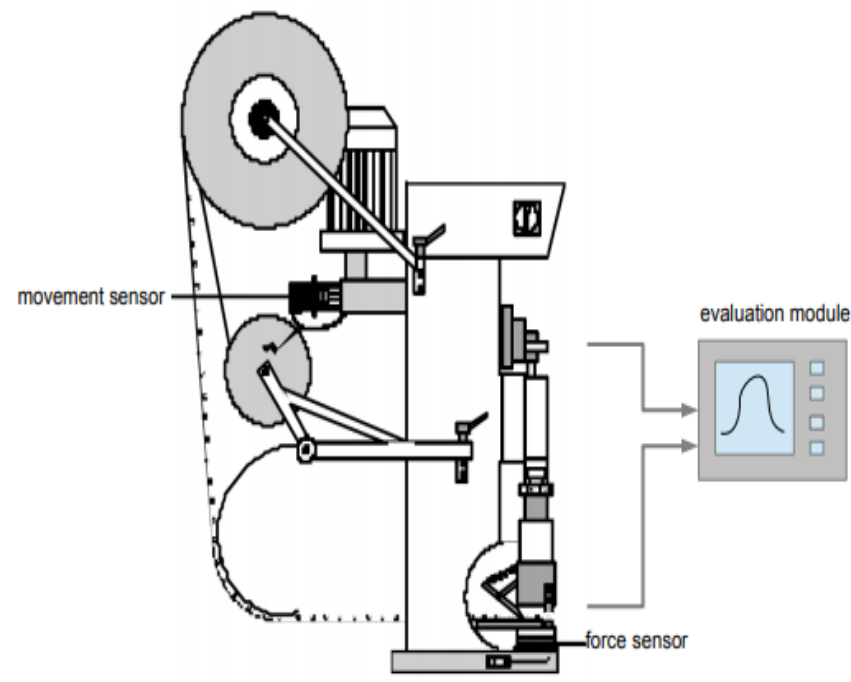

Figure 7. Combined use of press and crimp force analyzer (Schmid, 2013)

Each crimp process performed by the terminal crimp machine is monitored instantaneously and compared with the right crimp graph. As a result of the comparison, errors are detected.

In Figure 8, the interpretation of the force-time curve created by the crimp force analyzer is shown step by step. Figure 8(a) shows the typical crimp curve. By determining a threshold level in the force-time graph in Figure 8(b), the noise and discontinuity in the curve are ignored. In Figure 8(c), with the filter level line, the area where the terminal crimping process is performed, called the working area is determined.

The area of interest in the force curve is determined in Figure 8(d). Digital data in this range are read. In addition, the read data 
are interpreted by taking into account the error range that varies in each aplication. The peak value is determined in Figure 8(e). This value gives the breaking force of the crimped terminal. It is one of the interpretation criteria that is important. In Figure 8(f), with the analysis of Zone 1 can detect some faults caused by faulty terminals, and with the analysis of Zone 2, the performance of the terminal conductivity behavior can be determined.
The crimp force analyzer is added to the crimping machine externally or internally and the instant force curve of each crimping is acquired. Thus, possible fault situations are immediately detected and the crimping machine can be intervened to correct the fault situations. In addition, the process of obtaining data with the crimp force analyzer does not cause any damage as in the other operations described.
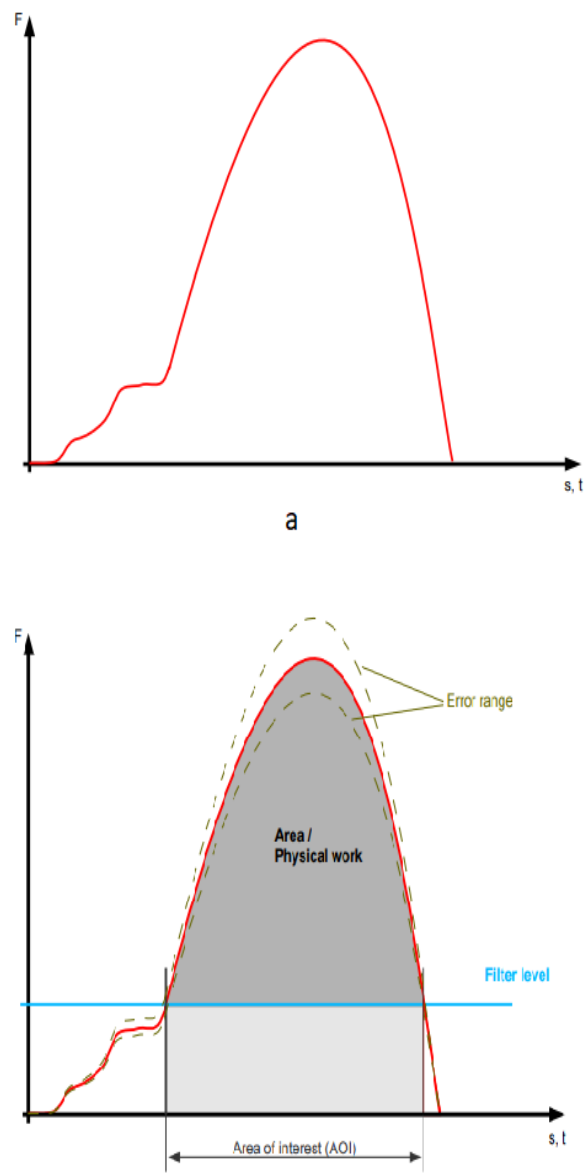

d

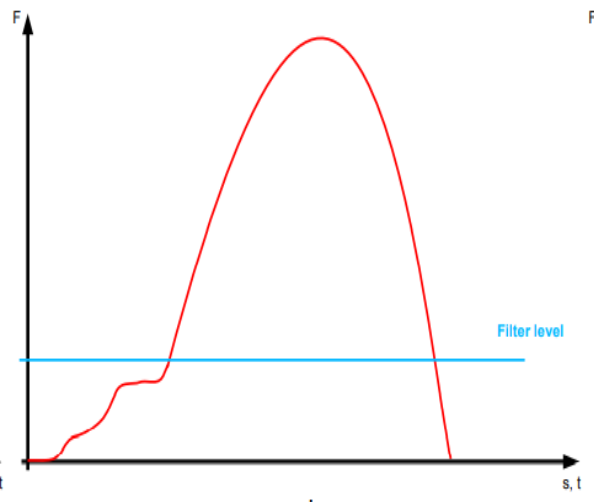

b

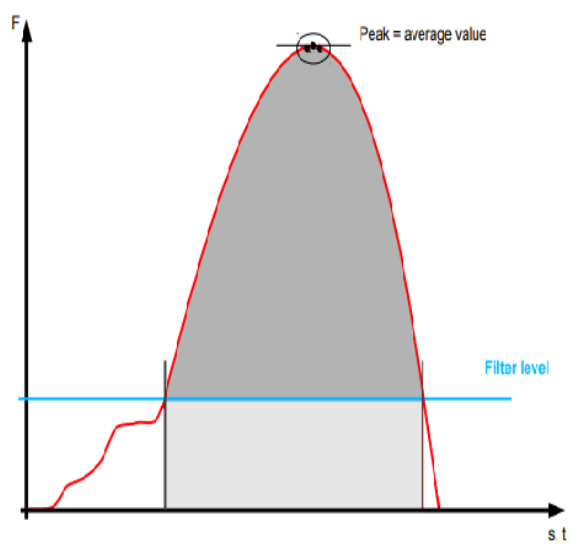

e
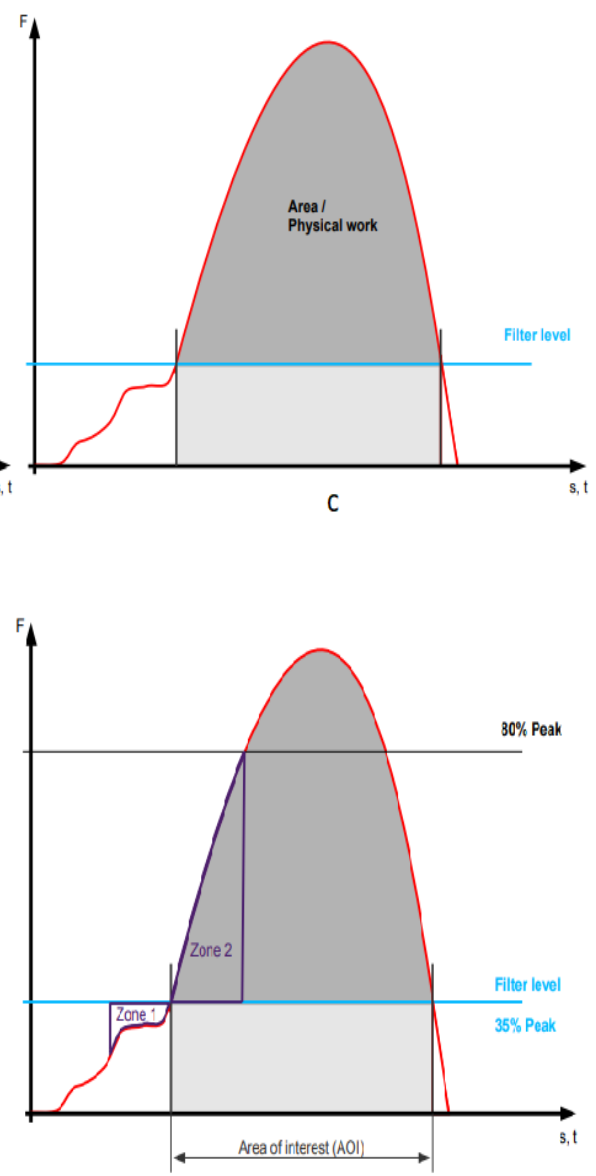

$f$

Figure 8. Interpretation of the force-time curve (Schmid, 2013)

\section{Results and Discussion}

In the study, the methods used to determine the quality of the terminal crimping process and industrial devices that determine the crimp quality using these methods were examined. Devices are classified according to the methods that are used, the advantages and disadvantages in Table 3.

Each method and device determines the crimp quality by interpreting data according to different criteria. It is sufficient to use the electrical test method and electrical test device in cases where the mechanical performance result is not required and only the quality determination is made based on the electrical performance result. However, this method tells only that crimping process is good quality or poor quality. The reason for poor quality can not be determined. In cases where it is desired to determine the cause of poor quality, cross-section imaging and force analysis methods should be used.

The examinations made with the cross-section imaging method and the crimp micrograph analyzer are performed by qualified personnel, but the examinations take a long time. In addition, there is a situation of wrong deciding due to personnel.

There are 2 devices in the force analysis method. The pull tester gives the result of good quality and poor quality crimping according to the breaking force at the end of the process and cannot detect the cause of poor quality crimping. On the other hand, the crimp force analyzer trasiently takes the force data at the start and end of the crimping process and creates the force curve. By interpreting the force curve, it determines the cause of poor quality crimping. In addition, since it works synchronously with the crimping machine, it may instruct the machine to stop the production in case of poor quality crimping. Thus, it prevents the emergence of faulty products. 
Table 3. Comparison of methods and devices that are used to determine terminal crimp quality

\begin{tabular}{|c|c|c|c|c|}
\hline Methods & Electrical Test & Cross-Section Imaging & \multicolumn{2}{|c|}{ Force Analysis } \\
\hline Device & Electrical Test Device & $\begin{array}{c}\text { Crimp Micrograph } \\
\text { Analyzer }\end{array}$ & Pull Tester & $\begin{array}{c}\text { Crimp Force Analyzer or } \\
\text { Monitoring }\end{array}$ \\
\hline Advantages & $\begin{array}{l}\text { The electrical performance } \\
\text { result is easily determined. } \\
\text { The test is performed in a } \\
\text { short time. } \\
\text { Qualified workforce is not } \\
\text { needed. } \\
\text { Test cost is low. }\end{array}$ & $\begin{array}{l}\text { Samples are examined in } \\
\text { detail. }\end{array}$ & $\begin{array}{l}\text { Mechanical performance is } \\
\text { determined } \\
\text { The test is performed in a } \\
\text { short time. } \\
\text { Qualified workforce is not } \\
\text { needed. } \\
\text { Test cost is low. }\end{array}$ & $\begin{array}{l}\text { Mechanical performance is } \\
\text { determined } \\
\text { The test is performed } \\
\text { instantaneously during the } \\
\text { crimping process. } \\
\text { Qualified workforce is not } \\
\text { needed. } \\
\text { There is no need for an } \\
\text { operator. } \\
\text { Deciding algorithm has } \\
\text { been developed. } \\
\text { It is a non-destructive } \\
\text { method. }\end{array}$ \\
\hline Disadvantages & $\begin{array}{l}\text { It does not provide } \\
\text { information about } \\
\text { mechanical performance. } \\
\text { It is difficult to decide only } \\
\text { based on electrical } \\
\text { performance results. }\end{array}$ & $\begin{array}{l}\text { The preparation of the sample } \\
\text { for test and testing takes a } \\
\text { long time. } \\
\text { Qualified workforce is } \\
\text { needed. } \\
\text { In order to perform the test, } \\
\text { laboratory and expensive test } \\
\text { equipment are required. } \\
\text { The operator is needed. } \\
\text { There is a possibility of } \\
\text { operator error. } \\
\text { It is a destructive method. }\end{array}$ & $\begin{array}{l}\text { The deciding algorithm } \\
\text { depends only on the } \\
\text { breaking value. So there is } \\
\text { a possibility of wrong } \\
\text { deciding. } \\
\text { It is a destructive method. }\end{array}$ & $\begin{array}{l}\text { Installation and device costs } \\
\text { are high. }\end{array}$ \\
\hline
\end{tabular}

\section{Conclusions and Recommendations}

The production capacity increase of many companies with the developing technology makes them potential customers of the ready-made cable manufacturing sector. In addition to the increasing production volume with each passing day, the cable manufacturing sector is constantly growing due to factors such as the fact that it is almost impossible to detect errors in manufacturing by eye.

This growth necessitates the completion of quality control processes with the least error and the fastest speed. In this study, quality control techniques in classic and IDC terminal crimping processes have been investigated.

Today, the use of new generation semi and fully automatic cable crimping machines that have very high annual production capacity is becoming widespread. These machines are structures containing advanced technology mechatronic systems and control software. Quality control processes must also be accelerated parallelly with the operation of the machines at very high speeds. As a result of quality control, the processed cable is expected to meet certain standards in terms of both electrical and mechanical strength. In this study, the advantages and disadvantages that should be taken into consideration in choosing the methods were analyzed.

In fact, many global white goods and automotive manufacturers get something done one or more of these methods mandatorily the companies that purchase ready-made cables. They may also request special tests (such as high voltage withstand tests) that are not included in this study. Therefore, due to the dynamic nature of the sector, although some of the test methods mentioned in the study have lower reliability values, 
their use continues, taking into account their superior aspects. With this study, it is aimed to contribute to the literature in the determining quality of terminal crimping. In the continuation of the study, applications can be made to demonstrate the effects of each method through experimental studies.

\section{References}

Camiresearch1. (2015). Improving Cable Quality \& Reliability Resistance Measurement to Within $1 \mathrm{~m} \Omega$. Retrieved from https://www.camiresearch.com/Campaigns/Web-Articles/4wire-testing.html

Camiresearch2. (2021). CableEye HVX System for High Voltage Cable and Harness Testing Datasheet. Retrieved from https://www.camiresearch.com/HVX_Photos/hipot_data_she et.pdf

Deveci, H. C. (2013). Proses Hata Türü ve Etkileri Analizi ve Kablo Kesim Sürecine Uygulanması. Kocaeli Üniversitesi Fen Bilimleri Enstitüsü, Yüksek Lisans Tezi.

Elliott, B. (2007). Electromechanical devices \& components illustrated sourcebook. McGraw-Hill Education, 151.

Fan, L., Gao, Y., Li, Q., \& Xu, H. (2012). Quality control on crimping of large diameter welding pipe . Chinese Journal of Mechanical Engineering, 25(6).

Knipex. (2019). Knipex PreciForce Crimping Pliers. Retrieved from https://www.knipex.com/products/crimpingpliers/knipex-preciforce-crimping-pliers/knipexpreciforcecrimping-pliers/975236

Mark-10. (2020). Wire Terminal Pull Tester Model WT3-201 Datasheet. Retrieved from https://mark10.com/products/wire-pull-testers/model-wt3-201/

Ocoleanu, C. F., \& Dolan, A. I. (2018). Experimental and Statistical Study of Connector Resistance Factor Influence on Crimping Validation Process. 2018 7th International Conference on Renewable Energy Research and Applications (ICRERA).

Ocoleanu, C.-F., Cividjian, G., \& Manolea, G. (2014). Solutions for quality pre-control of crimp contacts used in electric power systems and electrical machines. 3rd International Symposium on Environmental Friendly Energies and Applications (EFEA).

Ogihara, S., Takata, K., Hattori, Y., \& Yoshida, K. (2006). Mechanical Analysis of the Crimping Connection. . Proceedings of the 52nd IEEE Holm Conference on Electrical Contacts.

Rajak, A. K., \& Kore, S. D. (2017). Experimental investigation of aluminium-copper wire crimping with electromagnetic process: Its advantages over conventional process. Journal of Manufacturing Processes, 26, 57-66.

Rajak, A. K., \& Kore, S. D. (2018). Comparison of different types of coil in Electromagnetic terminal - wire crimping process: Numerical and experimental analysis. Journal of Manufacturing Processes, 34, 329-338.

Schleuniger1. (2019). Schleuniger CrimpCenter 36 S Fully Automatic Crimping Machine Datasheet. Retrieved from https://www.mtntech.com/wpcontent/uploads/2015/05/CC_36_S_DS_EN_A4_V8.pdf

Schleuniger2. (2018). Modular System for Crimp Cross-Section Analysis Datasheet. Retrieved from https://www.schleuniger.com/en/products/qualityassurance/crimp-micrograph-analysis/micrograph-system/
Schmid, T. (2013). Development of a New Crimp-QualityMonitoring System for Manually Operated Tools. University of Limerick Ollscoil Luimnigh, Master Thesis.

Standard1. (2018). Standard for Wire Connectors UL 486a-486b. Retrieved from https://standardscatalog.ul.com

Standard2. (2013). Standard IEC International Electrotechnical Commission, Crimped connections - General requirements, test methods and practical guidance IEC 60352-2. Retrieved from https://www.sis.se/api/document/preview/572141/

TEConnectivity. (2019). Crimp Quality Guidelines. Retrieved from https://www.te.com/content/dam/tecom/documents/application 